\title{
Journal of Educational
}

\section{Technology\&Online Learning}

Volume 4 | Issue $4 \mid 2021$

http://dergipark.org.tr/jetol

\section{Opinions and suggestions of classroom teachers in online mathematics education during the Covid-19 pandemic}

\author{
Veli TOPTAŞ a (D, Büşra USLUOĞLU a (D), Gökhan ŞENGÜN a * (D) \\ a Kirıkkale University, Turkey
}

Suggested citation: Topbaş, V., Usluoğlu, B. \& Şengün, G. (2021). Opinions and suggestions of classroom teachers in online mathematics education during the Covid-19 pandemic. Journal of Educational Technology \& Online Learning, 4(4), 880-895.

\begin{tabular}{ll}
\hline Article Info & Abstract \\
\cline { 2 - 3 } $\begin{array}{l}\text { Keywords: } \\
\text { Mathematics teaching } \\
\text { Classroom teachers } \\
\text { COVID-19 pandemic } \\
\begin{array}{l}\text { Online education } \\
\text { Phenomenology }\end{array}\end{array} \begin{array}{l}\text { This research was conducted to determine classroom teachers' positive and negative } \\
\text { experiences, opinions, and suggestions regarding online education and mathematics } \\
\text { teaching during COVID-19. A phenomenographic research method was used in the study } \\
\text { to achieve this aim. The sample group of the study consisted of 14 classroom teachers. } \\
\text { This research was conducted online using the semi-constructivist interview technique. In } \\
\text { this study, the answers to "How to teach mathematics with online education?", "What } \\
\text { are the positive and negative effects of online education on mathematics teaching?" and } \\
\text { "What can teachers, students, and parents do with mathematics education in this } \\
\text { process?" were sought. It was observed that during the COVID-19 pandemic, classroom } \\
\text { teachers entered a new process in online education and mathematics teaching. As a result } \\
\text { of the study, it was determined that students had difficulties while studying mathematics. } \\
\text { In addition, it was observed that classroom teachers make more effort to teach } \\
\text { mathematics in online education than in face-to-face teaching. Classroom teachers also } \\
\text { made various suggestions about successful mathematics education with online education } \\
\text { to students and parents. }\end{array}$ \\
Research Article &
\end{tabular}

\section{Introduction}

The coronavirus first appeared on December 31, 2019, in Wuhan, China, and in Turkey on March 11, 2020 (Ministry of Health 2020: 12-13). The virus, which is currently still spreading rapidly worldwide, has been defined by the World Health Organization as one that can cause respiratory tract infection and that can be transmitted through droplets (World Health Organization (WHO, 2020). COVID-19 is a highly contagious disease (Remuzzi \& Remuzzi, 2020). Due to its spread, necessary precautions have been taken, and vaccination studies continue. The WHO (2019) states that mask, distance, and hygiene measures should be followed. Due to the pandemic, necessary precautions have been taken in Turkey, as in every country. Countries have been affected by COVID-19 in terms of economics and education. It has also negatively affected nations in terms of health and social aspects. At the United Nations Conference on Trade and Development (UNCTAD, (2020), it was concluded that developing countries are the ones most economically affected by COVID 19. During the quarantine period, India's entire education system, from primary to higher education, collapsed (Mishra, Gupta \& Shre, 2020). The spread of the virus has led to the indefinite closure of schools and increased demand for distance education (Martinez, 2020). The pandemic

\footnotetext{
* Corresponding author: Kırıkkale University, Turkey

e-mail addresses: vtoptas@gmail.com, busrausluoglu38@hotmail.com,gkhansengun@gmail.com

This study was partly presented as a proceeding at the 1st International Conference on Educational Technology and Online Learning Conference held between 22-24 September 2021.
} 
has been recognized as a significant challenge for education systems. Tam and Al-Azar (2020) argued that there should be flexibility in education systems for the problems experienced in education due to the pandemic.

The pandemic has caused educational institutions to suddenly and in an unprepared way face and initiates online teaching. This situation has negatively affected students and teachers (Marinoni et al., 2020). Giannini and Lewis (2020) also stated that the inequality of opportunity, which creates gaps in education, will impact students negatively. Due to the disease and various restrictions, teachers, school administrators, and authorities have had to cope with the ongoing crisis. For example, the kinds of preparations institutions should make for COVID-19 and how they should determine the needs of students according to their level and field of study are crucial issues at present (Daniel, 2020).

\section{Literature}

During the first stages of the pandemic, Turkey focused on quickly closing health and education gaps, and necessary studies were carried out. As schools were on holiday, the education process was interrupted. However, the situation was handled in a short period of time. After studies were carried out by the Ministry of National Education, educational support started to be given over the internet and television (MEB, 2020). In addition, the production of masks, disinfectants, mask production machines, and respirators began with efforts to increase the production capacity in vocational high schools affiliated with the Ministry of National Education (MEB, 2020). In such an unexpected situation, quick and important decisions taken by Turkey and its Ministry of National Education have been crucial. Technology-based learning environments have brought different course designs and needs from traditional teaching (Ateş \& Altun, 2008). In previous years, teachers benefited from various presentation techniques for internet-based practical lessons: the materials used were of high quality, the font size and color arrangements were well adjusted, and this motivated students during lessons, providing them with continuous feedback and enabling the use of catchy summarization methods such as graphics and figures at the end of the lesson. In addition, suggestions were made such as keeping teacher-student interaction very high (Cosgrove, 2002; Elliot, 1995; Rutherford and Grana, 1994; Turnali, 2012). Some studies have stated that the issues to be considered while determining the content in internet-based online education programs should start from what is generally known. The scope and content of the information should be suitable to match the characteristics of the students (age, level of knowledge, etc.) (Şahan, 2005; Turnal1, 2012). In addition, distance education is a form of education that requires information and communication technologies at the highest level. The rapid development of digital information processing and communication creates many teaching and learning opportunities (Öztürk et al., 2018). Therefore, during this pandemic process, it has become necessary to make arrangements for distance education, which has become a necessity rather than a choice for education practitioners.

Homeschooling occurs through television and the internet, often straining and exhausting students and teachers. Self-sacrificing teachers, who put all their strength and skills into school education, try to do their best for their students in a home-based education environment. At the beginning of the pandemic in Turkey, students had to focus on education through television. Later, students communicated with their teachers online through the education network (EBA-Education Information Network) established by the Ministry of National Education. Later, they continued their education in this way. However, this situation began to cause problems for most students as many could not reach communication tools such as the internet and television. The content needing to be used in web-based online education, the planning and organizing of content development processes, planning and designing activities, e-library services to be provided to students, and planning and designing simultaneous live lessons are primary issues (Bilgiç Doğan, 2014). Researchers (Doğan and Koçak, 2020; Türker and Dündar, 2020) analyzed the technical and practical problems related to the EBA system. As a result, tablets and internet connections were provided to many 
students with the help of the Turkish government. In this way, the number of disadvantaged students has been reduced.

Like with all instruction, teaching mathematics requires a lot of preparation and seeks to find a unique place in the minds of students. Myers and Cannon (2018) suggested that you must first know, feel, and experience mathematics to learn the subject. Therefore, the student needs to make a special place for mathematics in his or her mind, internalize what he or she has learned, and reflect on it in real life. The teacher is one of the most important guides for students in their quest to feel and experience mathematics. Of course, schools are where this teaching takes place. The Ministry of National Education (MEB, 2018) aims to develop students' mathematical literacy skills and have learners use them effectively, understand mathematical concepts and use them in daily life, realize problem-solving processes, and make sense of the relationship between people and objects using mathematics. Positive attitudes towards mathematics are targeted and defined. However, the COVID-19 pandemic has also rendered mathematics teaching to online education. Kontrová (2015) emphasized that all possible educational options should be looked at in online mathematics teaching, and existing content, scope, and teaching methods should be transformed at all academic levels. This study aims to show how classroom teachers perform mathematics education through online education. In addition, it attempts to look at and analyze the suggestions of classroom teachers regarding the teaching of mathematics during the COVID-19 pandemic.

\section{Methodology}

\subsection{Research Model/Design}

Qualitative data collection techniques were used in this study. The qualitative research method phenomenography, which reveals people's experiences and focuses on sharing the meanings attributed to the phenomena by the individuals in the group, was used to analyze the research data. Phenomenographic research is concerned with how people perceive, understand, and experience the phenomena they encounter in the universe they live in. In phenomenographic studies, the explanations of individuals about a phenomenon are not evaluated as right or wrong. Individuals' definitions of the observed phenomenon (learning and teaching) are categorized, and these definitions clarify what individuals think (Koballa, Graber, Coleman, \& Kemp, 2000). Within the scope of this study, a phenomenological design was used to examine how classroom teachers, who directly experienced the pandemic's changes to education, effectuated their mathematics education. The research is limited to 14 classroom teachers interviewed in central Kayseri during the 2020-2021 academic year. In addition, it was assumed that the researchers sincerely asked the questions posed to the classroom teachers during the research process.

\subsection{Data Collecting Tools}

The questions prepared for the semi-structured interview to realize the aim of the study were evaluated by three academicians who are experts in the field of primary school mathematics education. The following questions were developed at the end in light of the positive and negative feedback from the experts:

1. How do you teach the mathematics lesson in the online education process? Can you evaluate the process with its positive and negative aspects?

2. What kind of studies or preparations do you do for teaching mathematics in the online education process?

3. In the online education process, what kind of positive or negative change do you observe in your students while teaching mathematics?

4. In your opinion, what kind of responsibilities do classroom teachers have to students and parents for the successful realization of mathematics teaching in the online education process? What would you recommend? 
Due to the COVID-19 pandemic, the data were collected through online interviews (Zoom meetings) made by the researchers in line with social distance measures. Interviews with each teacher lasted approximately 40 minutes. The interviews were recorded, and then the data were written down; feedback was received from the participants when deemed necessary.

\subsection{Study Group}

The working group of the research consists of teachers working in primary schools. The researchers used the easily accessible sampling method, one of the purposeful sampling types, in the selection of samples to ensure promptness and convenience due to the interruption of face-to-face education during the pandemic. The personal information of each classroom teacher participating in the study is shown in Table 1.

Table 1. Demographic information of participants.

\begin{tabular}{|c|c|c|c|c|}
\hline Code Name & Gender & $\begin{array}{c}\text { Professional } \\
\text { Seniority }\end{array}$ & Education Level & $\begin{array}{c}\text { Teaching Grade } \\
\text { Level }\end{array}$ \\
\hline T1* & $M$ & 22 & $\mathrm{~F}^{* *}$ & 3 \\
\hline $\mathrm{T} 2$ & M & 21 & $C^{* * *}$ & 3 \\
\hline T3 & M & 15 & $\mathrm{~F}$ & 3 \\
\hline $\mathrm{T} 4$ & $\mathrm{~F}$ & 11 & $\mathrm{~F}$ & 3 \\
\hline $\mathrm{T} 5$ & $\mathrm{M}$ & 12 & $\mathrm{~F}$ & 4 \\
\hline T6 & F & 12 & F & 4 \\
\hline $\mathrm{T} 7$ & $\mathrm{~F}$ & 19 & $\mathrm{C}$ & 4 \\
\hline T8 & $\mathrm{F}$ & 19 & $\mathrm{~F}$ & 1 \\
\hline T9 & $\mathrm{M}$ & 15 & $\mathrm{~F}$ & 4 \\
\hline T10 & F & 12 & F & 2 \\
\hline T11 & $\mathrm{F}$ & 14 & $\mathrm{~F}$ & 3 \\
\hline Ö12 & E & 19 & F & 3 \\
\hline Ö13 & E & 12 & F & 3 \\
\hline Ö14 & E & 15 & $\mathrm{~F}$ & 4 \\
\hline
\end{tabular}

As seen in Table 1, 6 of the teachers are female and 8 are male. Years of professional experience range from 11-22 years. Twelve of the participating teachers are university graduates and 2 are high school graduates. In the study, The aim was to also include teachers who teach classes at each primary school level. Of these, a maximum of 7 people are teaching 3 rd grade and at least one person is an instructor in $1 \mathrm{st}$ grade.

\subsection{Data Analysis}

The data were analyzed by descriptive analysis. The data collected in the descriptive analysis determine what was said or what kinds of results were presented in connection with the study's research problem. In this type of analysis, the researcher can often include direct quotations to reflect the views of the individuals they have met or observed. The primary purpose of this type of analysis is to present the obtained findings to the reader in a summarized and interpreted form (Y 1ldırım \& Şimşek, 2018). The categories and codes were determined by considering the questions in the interview form. After the groupings, comparisons were made between categories. The categories created by experts and researchers have thus taken their final form. The 14 teachers who participated in the study were numbered from T1 to T14, regardless of their name or institution. 


\subsection{Validity and Reliability}

In the research, the role of researchers is clearly articulated. The researchers reviewed the notes in the interviews with the participants, and direct quotations were made from the data sources. The data are described in a detailed, transparent, fair, and systematic way. In the research, the observations were presented impartially and transparently. In addition, to confirm what the researchers understood in terms of validity, interview transcripts were shown to the participants, and they were allowed to verify their input (Yıldırım and Şimşek, 2016; Brantlinger, Jimenez, Klingner, Pugachand Richardson, 2005; Creswell, 2020).

Before analyzing the research data, the prejudices and beliefs of the researchers related to the research topic were defined, and the researchers were provided with a statement of subjectivity (Baker, Wuestand Stern 1992; Yükseland Y1ldırım, 2015). As for research ethics, the researchers paid attention to the confidentiality of the participants and did not share their experiences with the participants during the interviews. The researchers gave the participants pseudonyms to ensure their privacy. The participants were informed about the confidentiality of the research and filled in the informed consent forms, in which they declared that they were voluntarily participating in the study. The role of researchers is essential in terms of being the person who establishes a one-to-one relationship with the participants and who encodes and categorizes the data (Creswell, 2020).

In addition, the researchers used techniques for monitoring, documenting, and evaluating the analytical process, which is vital for the reliability of the research. The participant role of the researchers in the study is clearly stated. Researchers created an internal audit tool and took notes, which enabled them to distance themselves from prejudices as much as possible and which increased the reliability and validity of the research. At the same time, the thoughts and reactions of the researchers were restricted (Kleiman, 2004; Kocabıyık, 2016; Kuzu, 2013; Uzuner, 1999; Yıldırım and Şimşek 2016; Starks and Trinidad, 2007). The researchers took the experts' opinions about education and measurement areas to ensure validity and reliability. The experts' opinions provided a more in-depth analysis of the data. In this way, the meaning of the data and the relationships between them were determined (Starks and Trinidad, 2007).

\subsection{Research Procedures}

In the study, which is a type of phenomenological research, the researchers wanted to have face-to-face interviews with the sample group members. However, due to pandemic restrictions, the researchers conducted online Zoom meetings with respondents. In line with the research, various questions were asked to the teachers by the researchers. The researchers recorded their conversations with the teachers during the Zoom meetings. During the research process, necessary precautions were taken by the researchers to attain the correct information. The research process and data are explained clearly and in detail. Categories and codes were created to analyze the research data.

\subsection{Findings and Discussions}

The questions in line with the research were: "How do you teach mathematics in the online education process? and "Can you evaluate the process with its positive and negative aspects?" According to the answers given by the teachers, the positive and negative aspects of the process were determined. The data obtained from the teachers are shown in Figure 1. 

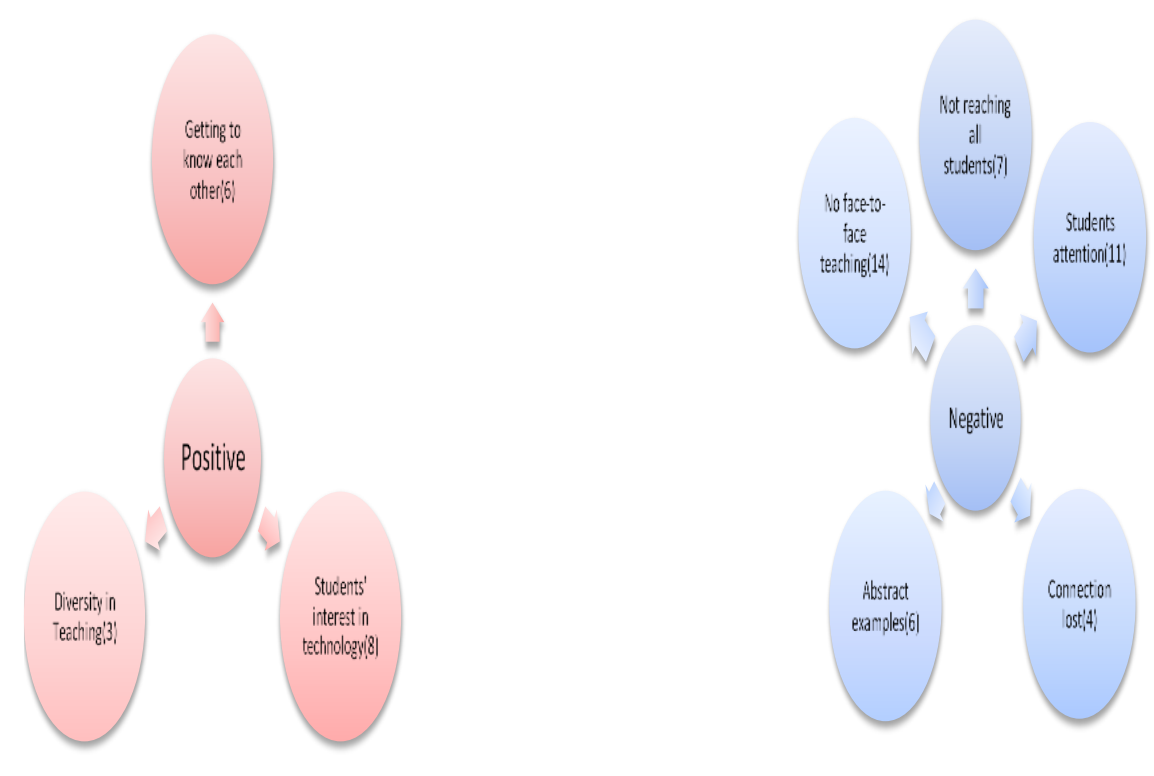

Fig. 1. Teachers' positive and negative opinions about the process.

Figure 1 shows teachers' positive and negative mathematics classroom evaluations in terms of online education. When they evaluated it positively, 6 of the teachers stated that they could maintain some of the classroom rules in online education because they knew their students. Three teachers said they benefit from online teaching and are able to show their students more material design, lectures, games, and songs than traditional education. In addition, 8 of the teachers said that they had a straightforward and positive process because of their students' interest in technology. The answers given by a few of the teachers on this subject are as follows:

T2: Yes, online education progresses very differently from face-to-face education. However, my students and I know each other. For example, it was impossible to talk and interrupt each other in our class without permission. We are trying to continue this rule in online education, as well.

T7: Since we started online education, I have offered more videos, songs, and game content over the internet in classes. Children say that they love education with songs and games in this way. I started to improve myself in the use of technology. I try to keep them focused and motivated as much as possible.

T1: Perhaps my most significant change in this process is that I work in a city center, and I have students with internet connections. In addition, my students' interest in technology and internet use also ensures that the lessons are fluent. Sometimes my students come to my aid and direct me when I have problems with the internet connections.

The answers given by the researchers to the question of "What kind of studies or preparations do you do in mathematics teaching in the online education process?" are shown in Figure 2 and categorized. 


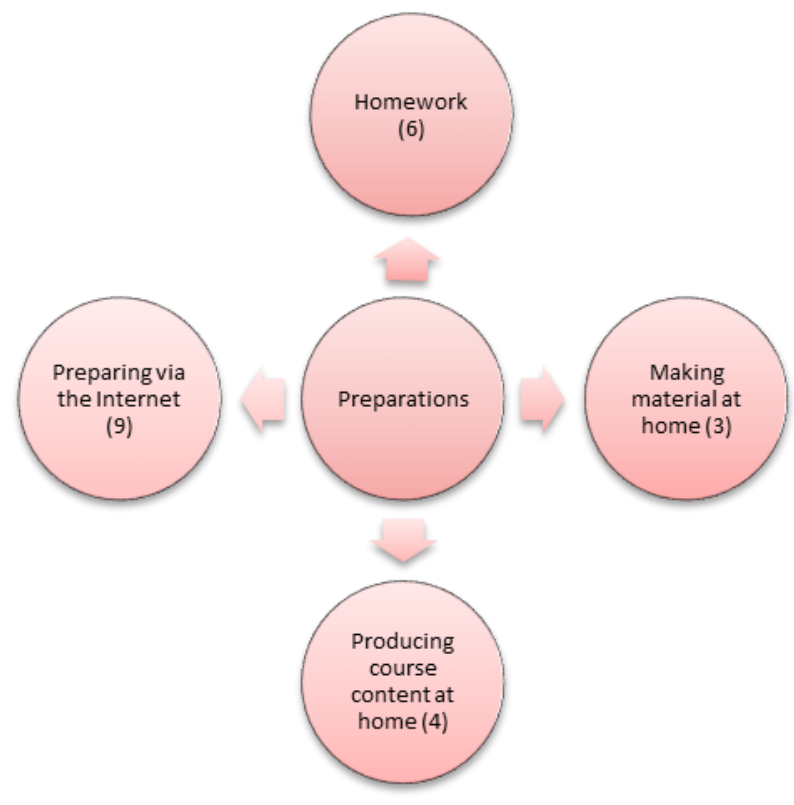

Fig. 2. Teachers' preparations.

As seen in Figure 2, 6 of the classroom teachers stated that they gave homework on the subjects they taught. Nine of the teachers indicated that they found a video or song suitable for the content of the special lesson for students on the internet before the mathematics lessons and that they did research before the lesson. Three teachers stated that they designed materials before the lesson or designed materials with their students to synchronize their students' minds to the teaching to be effectuated in the classroom. In addition, 4 of the teachers stated that they produced lesson content at home for teaching mathematics to their students, and they made an effort to ensure that the lessons were not only covered by the lectures. The answers given by a few of the teachers on this subject are as follows:

T11: I usually assign homework for students to practice on the subject I teach. At the end of the lessons, we give and check the answers to the assignments together.

T5: When we were in the classroom, we always sang songs and played games in a mathematics lesson. I research math-related games and songs before class in online education to motivate my students in the mathematics lessons.

T10: I generally like to go to my lessons by preparing materials for teaching mathematics in the classroom or we design and make materials with my children in the classroom. I did not want to lose this passion because we switched to online education with my children. Therefore, before the lessons, I design materials again or with them in the class such as colored papers, toys, etc. We use it as a material. We count them, we collect them, and we divide them.

T8: Since my students are only in their first year, I try to make the mathematics lesson tangible. I want children to learn by feeling, as I did in the classroom in the past. Therefore, I try to write a drama with them in online education, just like activities such as writing by feeling the numbers and games.

Next, the question "What kind of a positive or negative change do you observe in your students in teaching mathematics in the online education process?" was asked, and the answers were categorized and evaluated. Teachers' responses are shown in Figure 3. 


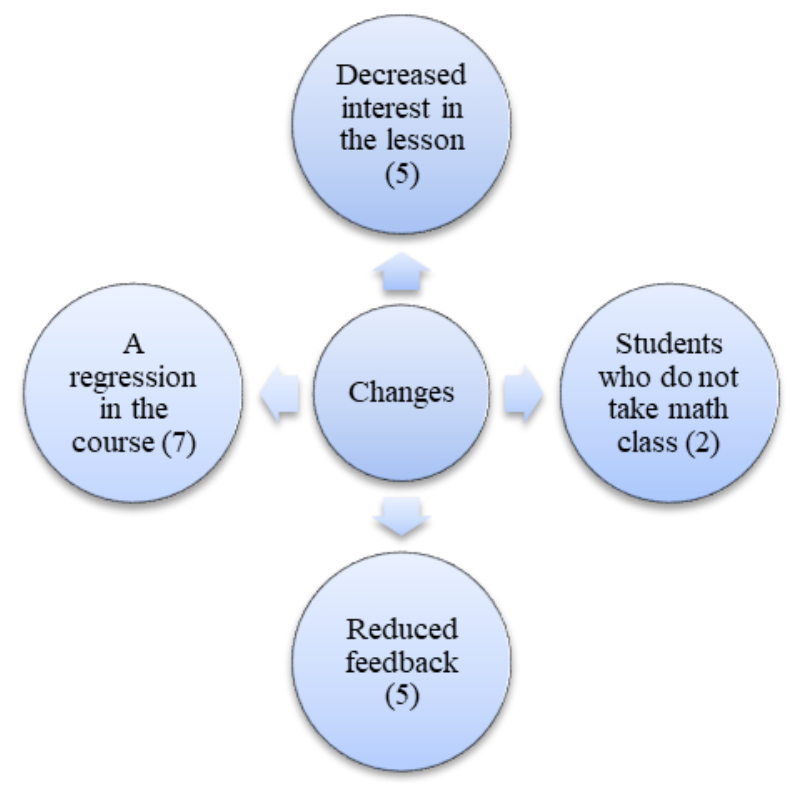

Fig. 3. The changes teachers observe in their students.

Figure 3 shows that classroom teachers generally observe and express negative changes in their students in the online education process during mathematics teaching. Seven of the teachers mentioned the decline in the overall teaching of the lesson, 5 of them mentioned a decrease in their students' interest in the lessons, 2 of them especially stated that their students did not attend the mathematics lesson, and 5 of them observed that the feedback during the lesson was considerably reduced. The answers given by a few of the teachers on this subject can be found below:

T12: I had negative observations in general. My students are experiencing a lot of regressions in math class. Most of them come to my class while at home with prejudice against mathematics. Last year, I was delighted that their interest in mathematics increased. However, during the pandemic process, I realized that most of my students closed their doors to mathematics. Some are very afraid that I will ask questions during the class.

T6: One of the saddest things I observed in this process is that most of my students do not attend the class. I especially have students who do not attend math classes and develop anxiety and fear towards math at home. I attach more importance to the 4th grade at the primary school level, but frankly, I am worried that I could not train my students as I wanted during the COVID-19 process.

T3: I observe that my students are less interested in mathematics and Turkish lessons in general.

T13: With the pandemic process, our communication with my students was generally affected. We seem to be losing our connection because we cannot make eye contact with the children. When I was in the classroom, we knew what each other wanted with my kids. Now, I don't get enough feedback, especially in math class. However, if we were in the classroom, that lesson would be very different. Honestly, when the math lesson is over, I do not know at what level which student learned.

An answer was sought for the questions, "What kind of responsibilities do classroom teachers, students, and parents have for successful mathematics teaching in the online education process? and "What do you recommend?" The answers are divided into titles and evaluated. Teachers' responses are shown in the following figures. 


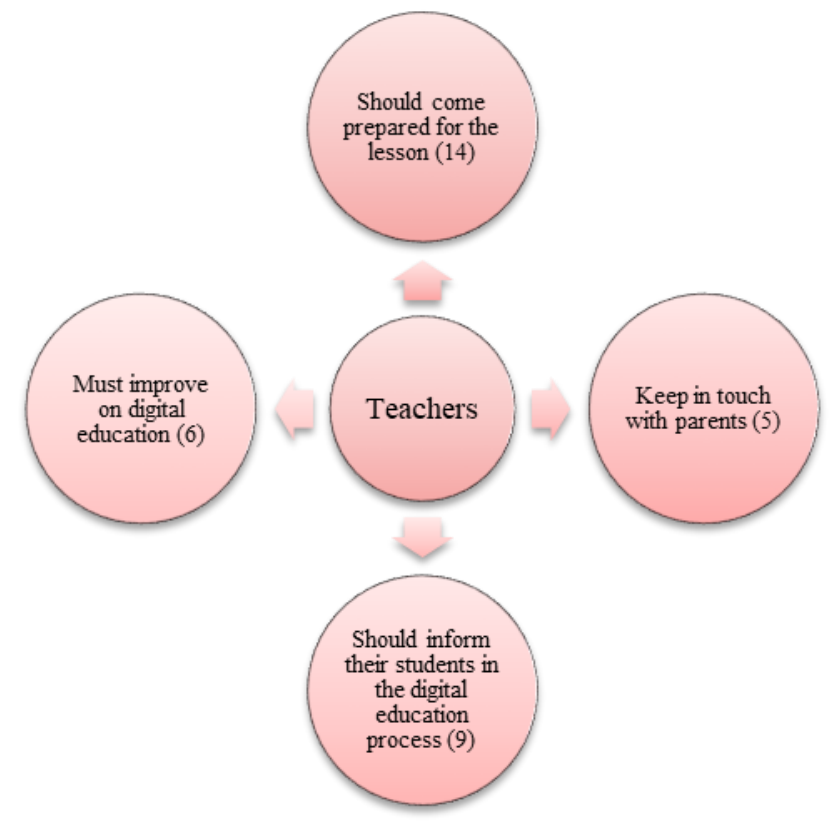

Fig. 4. Primary school teachers' suggestions to teachers in the online education process.

In Figure 4, according to the teachers participating in the study who were asked to make recommendations to other teachers in light of online education, 14 of them stated that teachers should come prepared for the lesson, 6 of them said that teachers need to educate themselves on technology and time planning to spend the online education process more efficiently, 5 of them mentioned that teachers should keep in touch with students' parents and follow up with students more frequently, and 9 of them expressed their views on how one should be informed about how to evaluate this online education process. Some of the answers given by the classroom teachers are as follows:

T14: Online education is not a technology field we have never known. In addition, it is one of the teacher's primary duties to prepare before the lesson. However, this extraordinary situation has brought about a new dimension to online education. Therefore, we should bring a new dimension to pre-lesson preparation for our teachers. For example, when it comes to teaching mathematics, the first thing that came to my mind was to blend mathematics with concrete examples at home.

T4: We brought technology and education together during this period. Teachers and students spend their time learning something new every day. Of course, teachers should be one step ahead of students in order to spend their lesson time more efficiently. I also follow my students' mathematics teaching by contacting parents. Sometimes, I advise my parents on this issue. I think that especially 1st grade students and their parents need us very much in this regard.

T11: Most of my students go through an inefficient process in online education. In the time remaining at the end of a lesson, I can recommend that teachers inform students about issues, listen to their problems, and solve them together. 


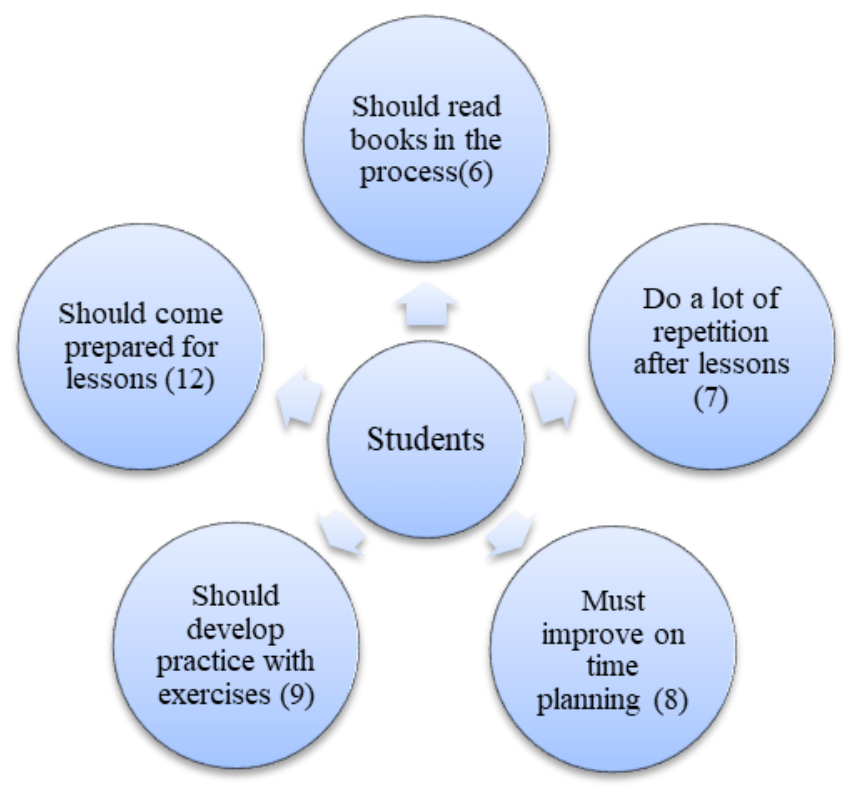

Fig. 5. Suggestions of classroom teachers to students in the online education process.

Figure 5 shows the advice given by classroom teachers to students to have an efficient mathematics education in the online education process. Six of the teachers mentioned that students should read books to understand what they have read. To improve development, 12 of the respondent teachers stated that students should prepare before the lessons, 7 of them observed that learners should repeat topics covered that day after the lessons, and 9 of them said that students should do a lot of math exercises after or before class. Eight of the teachers suggested that students who spent this process at home should improve themselves by planning to use their time correctly and efficiently. Some of the teachers' views are as follows:

T9: I am a teacher who believes in the relationship between success in mathematics and reading books. I can usually see students only on the screens in the online education process. I encourage my students to read books in class and follow them, but we are no longer in the classroom. That is why I recommend my students and all students to read books during this process.

T3: I think that students should be aware of the course and make preparations in the online education process, just as they prepare for the lessons in the classroom.

T5: Since we are in the 4th grade this year, I make my students practice mathematics lessons. I try to provide them with opportunities to practice and practice after the classes.

T10: It is a very different process for students. We, as teachers, need to make plans to use time efficiently, and students should also make plans about sleep regulation and study schedules. 


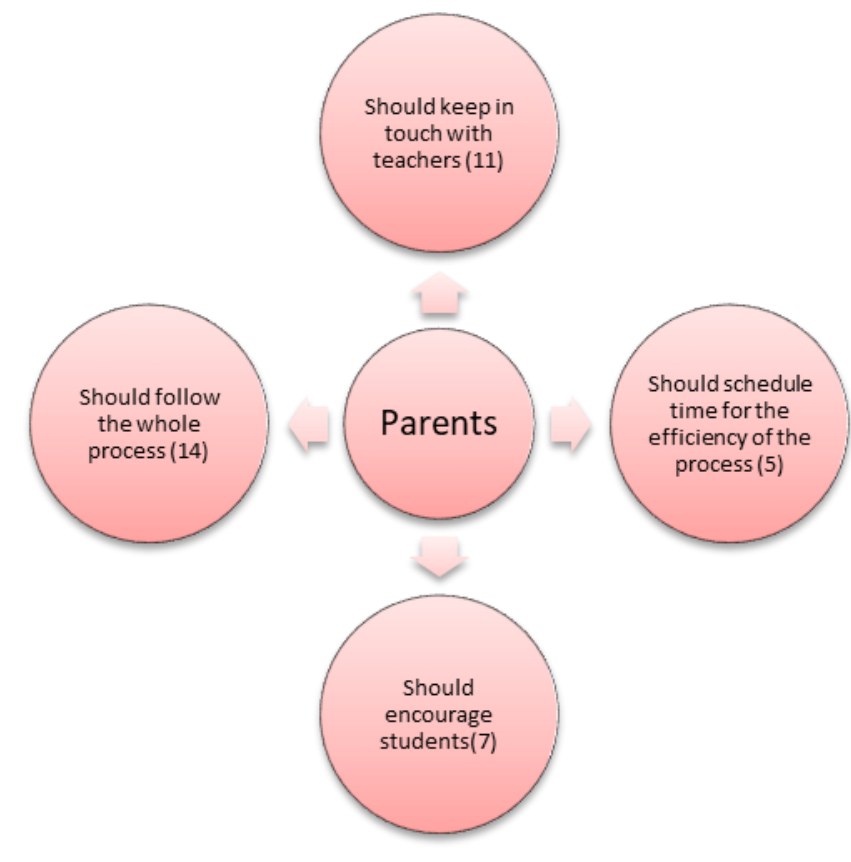

Fig. 6. Suggestions of classroom teachers to parents in the online education process.

Figure 6 shows the recommendations made by classroom teachers to parents for the efficiency of mathematics teaching in the online education process. Eleven of the teachers stated that parents should contact teachers in order to learn how to spend this process efficiently with their children at home. All parents should observe the students before, during, and after the math lesson. In other words, the parents should follow the whole process. Five of the teachers stated that parents should plan time for their students, and 7 of them said that parents should encourage their children to strive for mathematical achievements. Some of the teachers' views can be seen below:

T12: Of course, teachers and parents should communicate during this process. Thus, they can follow the students' progress together and give feedback to each other.

T13: In this process, the follow-up of the lessons should not only be left to the students, but the parents should take the responsibility that falls on them. Parents should be aware of lesson processes and homework and continue to follow up.

T4: The concept of 'time' always occurs in the education and training process. Therefore, teachers, students, and parents need to plan their time to manage this process, whether in school or during home education.

T2: In my opinion, students should have mathematics lessons in online education and face-to-face. Students should be encouraged by both their parents and teachers in this process to succeed in mathematics.

\section{Conclusion and Suggestions}

The COVID-19 pandemic has forced the world to shift from face-to-face to online education. Today, educators recognize the importance of online education in dealing with education and training challenges during the pandemic. In this study, teachers' positive and negative evaluations in teaching mathematics in the online education process were specified. Similarly, in Attardand Holmes' (2020) study, participants expressed positive and negative opinions about online education. In many studies, was determined that distance education does not give the desired results. For example, in Bayburtlu's (2020) study, teachers 
stated that some students could not attend live classes because they had no computer, tablet, or laptop. In addition, teachers noted that the level of attendance is not at the desired level, there are connection problems in distance education, and there are time restrictions. In addition, it was determined in the study that some parents were not interested in the process, did not monitor the students during distance education and, especially when both parents were working, their children were not controlled during the process. Teachers stated that the distance education process caused screen addiction in some students and that parents should be educated on this issue. It was also mentioned that it would be beneficial for teachers to receive training on digital content development. In Adnan and Anwar's study (2020), it was determined that most students could not access the internet due to technical and financial problems and that online learning did not give the desired results.

Lack of face-to-face interaction with the teacher, problems with response time, and lack of socialization in the classroom are disadvantages of distance education. Brooks, Webster, Smith, Woodland, Wessely, Greenberg, and Rubin (2020), Leung and Lamand Cheng (2020), and Karip (2020) also focused on the disadvantages of distance education. In this context, Çelikdemir (2020) emphasized that psychosocial support should be given to students during the pandemic process.

In addition, in a study conducted by Muthuprasad, Aiswarya, Aditya, and Jha (2021), classroom teachers stated that mathematics education entered a new distance education process during the COVID-19 pandemic and that students had difficulties in concretizing some mathematics concepts. Also, classroom teachers indicated that they spent more effort during online mathematics education to achieve educational gains than in face-to-face education. Although it has been determined in many studies that distance education does not give the desired results, its positive aspects have been determined in many studies. For example, Muthuprasad, Aiswarya, Aditya, and Jha (2021) highlights that some teachers use the internet much more in distance education. Teachers showed their students more material design, lessons, games, and songs in distance education than in regular education. In addition, some teachers stated that they could positively apply classroom rules in distance education.

Eight teachers stated that their students had an easy and positive experience due to their interest in technology. Studies (Mirzakhani, Ashrafzadehand Ashrafzadeh, 2010; Begimbetova, 2015; Attard and Holmes, 2020) show that online education expands education and provides equal education opportunities. Online education also saves time and money in the long term by providing flexible access to education in in terms of time and place (Rosenberg, 2001). Basilaia and Kvavadze (2020) also emphasized that students can be flexible about the online courses they take. The pandemic has also accelerated individuals' adaptation to the online education process (Yamamoto and Altun, 2020; Mulengaand Marbán, 2020; Cheng, 2020). This situation is consistent with the research findings. Online education has positive aspects regarding learners' time for self-study and adaptation to technology.

In this study, 6 of the classroom teachers stated that they gave homework on the subjects they taught. Nine of the teachers stated that they did research before the mathematics lesson and found videos or songs suitable for the lesson's content for children on the internet. Similarly, Basilaia and Kvavadze's (2020) research showed that assignments, projects, written assignments, and oral interviews could be preferred as an alternative to exams for assessment and evaluation. Three of the teachers said that they designed materials before or during the lesson with their students so that they would be similar to face-to-face teaching in the classroom; this also served to solidify the lesson in their students' minds. In addition, 4 of the teachers stated that they produced lesson content at home to teach mathematics to their students; these instructors made an effort to relate the content to daily life - not just to the topic's lesson.

Other findings of the study are the observations of classroom teachers about the negative changes in students in online mathematics and the teaching process in general. Seven of the teachers emphasized the decrease in the lesson's teaching, 5 mentioned the decline in their student's interest in the class, two complained about students who did not attend the mathematics lesson, and 5 of the teachers stated that 
feedback during the lesson significantly decreased. Cheng (2020) also noted the lack of course content and implementation, communication, interaction, and active participation in distance education as negative aspects of online teaching. Educational programs should be student-centered, students should actively participate, and interaction should be emphasized. It is thought that this situation cannot be achieved sufficiently through distance education. It has been stated that the inadequacy of students' participation in the courses online does not help teachers attain the desired efficiency. In addition, Karip (2020) and Çelikdemir (2020) emphasized that during the COVID-19 outbreak, internet infrastructure, lack of content, and not being able to access communication technologies were serious disadvantages for students. Muthuprasad, Aiswarya, Aditya, and Jha's study (2021) also showed that internet infrastructure and hardware problems in rural areas poses a problem for students and can limit the benefits of online education; for some, it is not possible to switch to a fully online model, and the authors stated that a hybrid model was needed.

Another finding of the study is that 14 of the teachers stated that they should come prepared for the lesson, and 6 of the teachers stated that they should receive training on technology and adequate time planning to provide online education. Five of the teachers said that it is necessary to communicate more frequently with the students' parents and follow the students more closely to make the educational process more efficient. In Attardand Holmes's study (2020), it was found that visualizing mathematical concepts in online mathematics education, teacher-student feedback, and communication will contribute to students' learning. In this study, 9 teachers stated their views on evaluating the online education process. Tezer and Cumhur's observations (2020) also show that during the COVID-19 outbreak, most students spent time and effort understanding mathematics in online lessons. In addition, it was observed that the number of those who were worried about not attending the online math class and those who did not participate were similar to each other.

Another finding of this study is that classroom teachers advise students on how to get an effective mathematics education in the online education process. Six of the teachers stated that students should read books to understand what they read, 12 of the teachers stated that students should prepare before the lesson, 7 of the teachers stated that the students should repeat the subjects taught after the lessons, and 9 of the teachers stated that the students should do a lot of mathematical exercises. Eight of the teachers noted that the students who spend this process at home should improve themselves by using their time correctly and efficiently. This research shows that classroom teachers are entering a new process in education with online math teaching during the COVID-19 pandemic. Classroom teachers also stated that students had difficulty concretizing mathematics in some situations. Concrete materials should be used as much as possible in teaching new concepts related to mathematics and in evaluations to be made (MoNE, 2018). Çelikdemir (2020) also emphasized that students should be supported academically. In this context, it is vital to find the necessary materials in specific learning environments and use them effectively (Halat, 2007; Keleş, 2009; Korkmaz, 2006; Köse, 2011; Ocak and Tepe, 2019; Orbeyi, 2007; Temli Durmuş, 2016; Fuentes and Ma, 2018).

Teachers' experiences are significant in online math education. When the study's findings are examined, it is worth noting that some participants have positive opinions about online mathematics education and some participants have negative views. We also find that teachers have observed negative changes in students, progress. In addition, internet infrastructure problems and the lack of equipment cause inequality of opportunity among students throughout the process. There are difficulties in concretizing the activities in online mathematics education. It is recommended that instructors use concrete materials as much as possible so that online mathematics education can be applied more effectively. The current study conducted on online math education during the COVID-19 pandemic can also be carried out in different research areas. During the COVID-19 pandemic, different studies can be conducted to address the opinions of other branch teachers who teach online. 


\section{References}

Adnan, M., \& Anwar, K. (2020). Online Learning amid the COVID-19 Pandemic: Students' Perspectives. Online Submission, 2(1), 45-51.

Ates, A. \& Altun, E. (2008). Investigating preservice computer teachers' attitudes towards distance learning regarding various variables. GU, Gazi Egitim Fakultesi Dergisi, 28(3), 125-145.

Attard, C. Holmes, K. (2020). An exploration of teacher and student perceptions of blended learning in four secondary mathematics classrooms. Math Ed Res J https://doi.org/10.1007/s13394-020-00359-2.

Baker, C., Wuest, J. \& Stern, P.N. (1992). Method Slurring: The Grounded Theory/ Phenomenology Example. Journal of Advanced Nursing, 17(11), 1355-1360. https://doi.org/10.1111/j.13652648.1992.tb01859.x

Basilaia, G., \& Kvavadze, D. (2020). Transitioning to online education in schools during a SARS-CoV-2 coronavirus (COVID-19) pandemic in Georgia. Pedagogical Research, 5 (4).

Bayburtlu, Y. S. (2020). Covid-19 pandemi dönemi uzaktan eğitim sürecinde öğretmen görüşlerine göre Türkçe eğitimi. Electronic Turkish Studies, 15(4).

Brantlinger, E., Jimenez, R., Klingner, J., Marleen, P. \& Virginia, R. (2005). Qualitative Studies in Special Education. Exceptional Children, 71(2), 195-207. https://doi.org/10.1177/001440290507100205

Begimbetova, K, (2015). Satisfactory level of teachers and students in distance learning. Master Thesis, University of Gazi.

Bilgiç Doğan, H. G. (2014). Yükseköğretim Kurumlarında Web Tabanlı Uzaktan Eğitim Programları Bileşenleri: Uygulamalar ve Sorun Alanları (DoktoraTezi). Hacettepe Üniversitesi, Eğitim Bilimleri Enstitüsü, Bilgisayar ve Öğretim Teknolojileri Eğitimi Anabilim Dalı, Yayınlanmamış Doktora Tezi Ankara.

Brooks, S. K., Webster, R. K., Smith, L. E., Woodland, L., Wessely, S., Greenberg, N., \& Rubin, G. J. (2020). The psychological impact of quarantine and how to reduce it: rapid review of the evidence. The lancet, 395 (10227), 912-920.

Cheng, X. (2020). Challenges of' school's out, but class's on to school education: a practical exploration of Chinese schools during the COVID-19 pandemic. SCI Insight Edu Front, 5 (2), 501-516.

Creswell, J. W. (2020). Nitel Araştırma Yöntemleri: Beş Yaklaşıma Göre Nitel Araştırma ve Araştırma Deseni, (Çev. Ed: Bütün, M. \& Demir, S.B.). 5. Bask1, Ankara: Siyasal Kitabevi.

Çelikdemir, K. (2020). Continuing learning in the COVID-19 outbreak, Ankara, Türk Eğitim Derneği Yayınlar1.

Doğan, S., \& Koçak, E. (2020). EBA sistemi bağlamında uzaktan eğitim faaliyetleri üzerine birinceleme. Ekonomi ve Sosyal Araştırmalar Dergisi, 7(14), 111-124.

Fuentes, S. Q., \& Ma, J. (2018). Promoting teacher learning: A framework for evaluating the educative features of mathematics curriculum materials. Journal of Mathematics Teacher Education, 21 (4), 351-385.

Giannini, S., \& Lewis, S. G. (2020). Three ways to plan for equity during the coronavirus school closures. Retrieved from World Education Blog: https://gemreportunesco. WordPress. $\mathrm{COM} / 2020 / 03 / 25 /$ three-ways-to-plan-for-equity-during-the-coronavirus-school-closures. 
Holt, E. (2007). Yeni ilköğretim matematik programı (1-5) ile ilgili sınıf öğretmenlerinin görüşleri. Afyon Kocatepe Üniversitesi Sosyal Bilimler Dergisi, 9 (1), 63-88.

Karip E. (2020). COVID-19 schools closed and after, Ankara, TürkEğitimDerneğiYayınları.

Keleş, Ö. (2009). An investigation of elementary and mathematics teachers' views about the new elementary school mathematics curriculum. Yüksek Lisans Tezi, Orta Doğu Teknik Üniversitesi, Sosyal Bilimler Enstitüsü, Ankara.

Kleiman, S. (2004). Phenomenology: To Wonder and Search for Meanings. Nurse Researcher, 11(4), 7-19. https://doi.org/10.7748/nr2004.07.11.4.7.c6211.

Koballa Jr, T., Graber, W., Coleman, D. C., \& Kemp, A. C. (2000). Prospective gymnasium teachers' conceptions of chemistry learning and teaching. International Journal of Science Education, 22 (2), 209-224.

Kocabıyık, O. (2016). Olgubilim ve Gömülü Kuram: Bazı Özellikler Açısından Karşılaştırma, Trakya Üniversitesi Eğitim Fakültesi Dergisi, 6(1), 55-66. https://dergipark.org.tr/en/download/articlefile/200424

Kontrová, L. (2015). Mathematical Learning In Online Education Space. University of Zilina (Slovakia).

Korkmaz, İ. (2006). Yeni İlköğretim Birinci Sınıf Programının Öğretmenler Tarafından Değerlendirilmesi. Selçuk Üniversitesi Sosyal Bilimler Enstitüsü Dergisi, (16), 419-431.

Köse, E. (2011). İlköğretim Matematik Programının Eğitsel Eleştiri Modeline Göre Değerlendirilmesi. Adnan Menderes Üniversitesi Eğitim Fakültesi Eğitim Bilimleri Dergisi, 2(2), 1-11.

Kuzu, A. (2013). Araştırmaların Planlanması. A. A. Kurt (Ed.), Bilimsel Araştırma Yöntemleri İçinde (ss. 19-45). Eskişehir: Anadolu Üniversitesi Yayınları.

Marinoni, G., Van't Land, H., \& Jensen, T. (2020). The impact of Covid-19 on higher education around the world. IAU Global Survey Report.

Martinez, J. (2020). Take this pandemic moment to improve education. EduSource. Retrieved from https://edsource.org/2020/take-this-pandemic-moment-to-improveeducation/633500.

Millî Eğitim Bakanlığı. (2018). Matematik Dersi Öğretim Programı (1,2,3,4,5,6,7ve 8. Sınıflar). Ankara: Yazar.

Millî Eğitim Bakanlığı. (2020b). EBA TV ders yayını, it was obtained from https://www.eba.gov.tr/web on April 02, 2020.

Mirzakhani, M., Ashrafzadeh, H., \& Ashrafzadeh, A. (2010). The virtual university: Advantages and disadvantages. In 2010 4th International Conference on Distance Learning and Education (pp. 3236). IEEE.

Mishra, L., Gupta, T., \& Shree, A. (2020). Online teaching-learning in higher education during lockdown period of COVID-19 pandemic. International Journal of Educational Research Open, 1, 100012.

Mulenga, E. M., \& Marbán, J. M. (2020). Is COVID-19 the gateway for digital learning in mathematics education?. Contemporary Educational Technology, 12 (2), ep269.

Muthuprasad, T., Aiswarya, S., Aditya, K. S., \& Jha, G. K. (2021). Students' perception and preference for online education in India during COVID-19 Pandemic. Social Sciences \& Humanities Open, 3 (1), 100101.

Myers, K., \& Cannon, S. O. (2018). Looking inward: (Re) negotiating and (re) navigating mathematics teacher beliefs as teacher educators, students and scholars. 
Ocak, G., \& Tepe, M. E. (2019). Evaluation of 5th Grade Turkish, Mathematics Curriculum According to Students' and Teachers' Views. Malaysian Online Journal of Educational Sciences, 7 (1), 23-34.

Orbeyi, S. (2007). İlköğretim matematik dersi öğretim programının öğretmen görüşlerine dayalı olarak değerlendirilmesi. Yüksek Lisans Tezi, Çanakkale Onsekiz Mart Üniversitesi, Sosyal Bilimler Enstitüsü, Çanakkale.

Ozturk, D. S., Ozturk, F., \& Rasit, O. Z. E. N. (2018). The relationship between prospective teachers' readiness and satisfactions about internet-based distance education. Turkish Online Journal of Distance Education, 19(1), 147-162.

Remuzzi, A., \& Remuzzi, G. (2020). COVID-19 and Italy: What next? Lancet, 395, 1225-1228. 10.1016/S0140-6736(20)30627-9.

Sağlık Bakanlığı (2020). Turkey daily coronavirus table. It was obtained from https://covid19.saglik.gov.tr/web on February 14, 2021.

Starks, H., \& Trinidad, S. B. (2007). Choose Your Method: A Comparison of Phenomenology, Discourse Analysis, and Grounded Theory. Qualitative Health Research, 17(10), 1372-1380. https://doi.org/10.1177/1049732307307031

Tam, G., \& El-Azar, D. (3). Ways the coronavirus pandemic could reshape education. In World Economic Forum.

Temple Durmus, Y. (2016). Effective Learning Environment Characteristics as a Requirement of Constructivist Curricula: Teachers' Needs and School Principals' Views. International Journal of Instruction, 9 (2), 183-198.

Tezer,M., \& Cumhur, M. G. (2020). Salgın Hastalık Sürecinde Çevrimiçi Matematik Dersine Yönelik Öğrenci Görüşleri. In Conference Proceedıng Book (p. 88). Near East University.

Turnalı, A. (2012). Uzaktaneğitimde internet tabanlı eğitim programlarının temel boyutlarına yönelik öğrenci ve öğretim elemanlarının görüşleri ve öneriler (Yayımlanmamış doktora tezi). Mersin Üniversitesi.

Türker, A., \& Dündar, E. (2020). COVID-19 Pandemi Sürecinde Eğitim Bilişim Ağı (EBA) Üzerinden Yürütülen Uzaktan Eğitimlerle İlgili Lise Öğretmenlerinin Görüşleri. Milli Eğitim Dergisi, 49 (1), 323-342.

Uzuner, Y. (1999). Niteliksel Araştırma Yaklaşımı. A. A. Bir (Ed.), Sosyal Bilimlerde Araştırma Yöntemleri İçinde (ss.175-190). Eskişehir: Anadolu ÜniversitesiYayınları.

World Health Organization. (2020). Mental health and psychosocial considerations during the COVID-19 outbreak, March 182020 (No. WHO/2019-nCoV/MentalHealth/2020.1). World Health Organization.

Yamamoto, T. G., \&Altun, D. (2020). The Coronavirus and the Rising of Online Education. Üniversite Araştırmaları Dergisi, 3(1): 25-34.

Yıldırım, A. \&Şimşek, H. (2016). Sosyal bilimlerde nitel araştırma yöntemleri. Ankara: SeçkinYayıncılık.

Yıldırım, A., \& Şimsek, H. (2018). SosyalBilimlerdeNitelAraştırmaYöntemleri. (11. Baskı). Ankara: Seçkin.

Yüksel, P. \& Y1ldırım, S. (2015). Theoretical Frameworks, Methods, and Procedures for Conducting Phenomenological Studies in Educational Settings. Turkish Online Journal of Qualitative Inquiry, 6(1), 1-20. https://doi.org/10.17569/tojqi.59813 